3-7-2010

\title{
Protecting New Mexico's Waters: A Blueprint for the Future
}

Denise D. Fort

University of New Mexico - School of Law

Follow this and additional works at: https://digitalrepository.unm.edu/law_facultyscholarship

Part of the Environmental Law Commons, and the Water Law Commons

\section{Recommended Citation}

Denise D. Fort, Protecting New Mexico's Waters: A Blueprint for the Future, [White Paper] 1 (2010).

Available at: https://digitalrepository.unm.edu/law_facultyscholarship/731

This Article is brought to you for free and open access by the UNM School of Law at UNM Digital Repository. It has been accepted for inclusion in Faculty Scholarship by an authorized administrator of UNM Digital Repository. For more information, please contact amywinter@unm.edu, Isloane@salud.unm.edu, sarahrk@unm.edu.

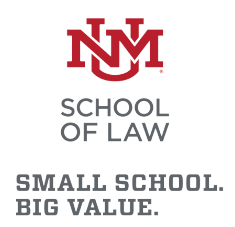




\title{
PROTECTING NEW MEXICO'S WATERS: A BLUEPRINT FOR THE FUTURE
}

\author{
Professor Denise D. Fort ${ }^{1}$ \\ March 6, 2010 \\ Working Draft
}

\section{INTRODUCTION}

New Mexico is an arid state, with a growing population, and declining groundwater aquifers. The prior appropriation doctrine was the means of allocating most of the state's surface waters and waters were appropriated, as they were throughout the western U.S., at a time when the state's economic base was agriculture. The legacy remains; the USGS estimates that $78 \%$ of all water is withdrawn by the agricultural sector. Scarcity of water has not been an effective constraint on urban development; new developments are approved by municipal authorities with an assumption that the water district will procure water, or in some cities, based on a developer's promise to secure water. Climate change and population pressures continue to exert pressure on water supplies, and the state's ongoing depletion of groundwater reserves requires that alternative water supplies be located and moved to urban areas. As regional shortages occur, the state has invested in pipelines as the solution, in which waters are moved from one region, or even a different basin, to another. The massive San Juan- Chama diversion project is an example of this, but pipeline projects are underway across the state to move water to areas of population growth, or areas where groundwater has been depleted. In another example, Gallup will be the beneficiary of such a pipeline, with federal funding provided as part of the Navajo water settlement.

There are multiple ways in which New Mexico's water policies could be improved, but the focus of this paper is on the ecological conditions of the state's waters. Ecological health has several dimensions, including water quality, riparian conditions, water temperatures, sediment movement, constructed facilities, the presence of species, etc. Environmental flows have been neglected by state water managers and are the most critical aspect of protecting river health. Indeed, in a state where main stem rivers are periodically allowed to go dry, measures aimed at improving other aspects of river condition seem a bit incongruous. We contend that the ecological aspects of rivers are poorly protected by state government policies. The state does not have a program to protect these values, it lacks adequate legal institutions to do so, political leadership to protect rivers is thin, and major sectors of the state's economy are at work seeking the development of any and all available water resources.

\footnotetext{
${ }^{1}$ Denise Fort is a faculty member at the University of New Mexico School of Law and a long time advocate for river protection. She wishes to express her thanks to the McCune, Turner and Kenney Foundations for their support of this work. In addition, she appreciates the contributions of Ernesto Longo, UNM Library. Finally, thanks to Beth Bardwell, National Audubon Society, and others who commented upon this draft. Additional comments are solicited: please direct to fortde@law.unm.edu.
} 
The state's water allocation policies have ignored environmental values for over a century, but the tide is turning within the state. A growing movement to protect rivers is glimpsed in activities of NGOs, as activists try to protect the silvery minnow, improve water quality in mountain rivers, protect the Gila River, restore streams, and bring rivers back to life. The question for this paper is what strategies would be most productive to protect and restore our rivers.

The paper begins with an overview of how the state's water resources are managed and allocated, because the demands on rivers occur in this broader context of water allocation and use. It reviews the programs that the state currently has for protection and restoration. The heart of the paper is a discussion of the strategies that can be utilized to improve New Mexico rivers.

\section{WATER RESOURCES IN NEW MEXICO}

New Mexico bifurcates its water management into water quantity and water quality management. The state established a water resources code in 1907 and has a system for administration of water rights under the Office of the State Engineer. It also is party to interstate compacts on its major rivers, with deliveries assured by the Interstate Stream Commission. Unlike many western states, New Mexico recognized the importance of groundwater resources and addressed them within its administrative schema in 1931.

\section{Water Quality}

Water quality was brought within the federal structure for pollution control shortly after passage of the Federal Water Pollution Control Act (popularly known as the Clean Water Act) in 1972. New Mexico had stream standards that predated the federal act and has continued to refine them within the state and federal framework. The state also has a regulatory program to protect groundwater quality from contamination. It has divided administration of water quality protection among several agencies (the Environment Department; Energy, Minerals and Natural Resources; Department of Agriculture), presumably at the behest of the most powerful regulated industries. Significantly, the state does not administer the point source pollution program of the federal clean water act $^{2}$ so that the federal EPA still plays a major role in regulating point source pollution within the state. NM does not regulate most forms of nonpoint source pollution, nor does it have a state equivalent of the federal program to protect waters of the state from "dredging and filling.", 3

Water quality in New Mexico is measured by comparison to the standards that are established by the state, not to national numeric limitations (unlike air quality, for example). This means that there is not a uniform established baseline for water quality

\footnotetext{
2 The National Pollutant Discharge and Elimination System, known as a NPDES permit.

${ }^{3}$ Section 404 of the Clean Water Act requires a federal permit from the U.S. Corps of Engineers for dredging and filling in protected waters of the U.S. While these permits are required for some of New Mexico's waters, the scope of the federal law is limited in New Mexico, as is discussed below.
} 
across the states and water quality standards tend to reflect the economic status of states. The state reports to Congress on a triennial basis to Congress about its progress towards meeting those goals. ${ }^{4}$

\section{Water Allocation}

Water rights are administered by the Office of the State Engineer, under the direction of a professional engineer who is appointed by the Governor. The Interstate Stream

Commission $^{5}$ is under the State Engineer; the director of the Commission is the deputy State Engineer and the State Engineer is the Secretary of the Commission.

\section{Water Use and Water Economics}

The Office of the State Engineer gathers data about the use of water in New Mexico. From a water management perspective, groundwater is the most important source of water in the state; it accounts for $87 \%$ of all public (municipal) water supplies. (OSE 2005) These water users are not able to withstand large disruptions in delivery and thus require a highly reliable supply. They also pay the most for water: a fact that helps account for the adage that "water flows uphill to money." Groundwater accounts for $46 \%$ of total water withdrawals in the state, with most of the total volume consumed by agriculture. By any definition of sustainability, groundwater typically is not a sustainable source of water in New Mexico because many basins are being mined (not recharged at the rate at which they are being depleted). Surface waters are renewable, although subject to natural variability and climate change.

Agriculture withdraws $78 \%$ of all water (surface and groundwater) in the state. (The United States Geological Survey also measures the consumptive use of water; agriculture returns less water to streams because it has a higher consumptive use). ${ }^{6}$

The agricultural sector in the state is dominated by the relatively new dairy industry. ${ }^{7}$

\footnotetext{
${ }^{4}$ New Mexico Environment Department, 2006-2008 State of New Mexico Integrated Clean Water Act $\S 303(d) / \S 305(b)$ Report, available at http://www.nmenv.state.nm.us/swqb/303d-305b/2006-2008/20062008NMIntegrated303d-305bReport.pdf

${ }^{5}$ N.M. STAT. ANN. §72-14-1 to -44 (West 2009).

${ }^{6}$ U.S. Geological Survey (USGS), Annual Water Data Reports, http://wdr.water.usgs.gov

${ }^{7}$ http://www.ers.usda.gov/Statefacts/NM.HTM; Denise Fort and Anthony Edwards, Dairies in New Mexico: The Environmental Implications of a New Industry. State Bar of New Mexico, Natural Resources, Energy and Environmental Law Section Newsletter, Summer 2009. http://ssrn.com/abstract=1446816
} 


\begin{tabular}{|l|r|r|r|}
\hline Top 5 agriculture commodities, 2007 & \multicolumn{3}{|c|}{} \\
\hline & $\begin{array}{r}\text { Value of receipts } \\
\text { thousand \$ }\end{array}$ & $\begin{array}{r}\text { Percent of state } \\
\text { total } \\
\text { farm receipts }\end{array}$ & $\begin{array}{r}\text { Percent of US } \\
\text { value }\end{array}$ \\
\hline 1. Dairy products & $1,353,788$ & 44.3 & 3.8 \\
\hline 2. Cattle and calves & 951,847 & 31.1 & 1.9 \\
\hline 3. Hay & 195,406 & 6.4 & 3.1 \\
\hline 4. Pecans & 96,200 & 3.1 & 22.1 \\
\hline 5. Onions & 63,440 & 2.1 & 4.8 \\
\hline \hline & \multicolumn{3}{|r}{} \\
\hline All commodities & $3,057,901$ & & \\
\hline
\end{tabular}

Much of the state's lands are used in grazing, in fact about $58 \%$ of the entire land base. ${ }^{8}$ Irrigated farm lands are a small percentage of the state's agricultural lands.

Most of the agricultural products come from the southern part of the state, reflecting the location of each of the crops and the dairies above.

\begin{tabular}{|l|r|r|}
\hline Top 5 counties in agricultural sales 2002 & $\begin{array}{r}\text { Percent of state } \\
\text { total receipts }\end{array}$ & Million \$ \\
\hline 1. Chaves County & 16.7 & 283.9 \\
\hline 2. Dona Ana County & 14.8 & 251.8 \\
\hline 3. Curry County & 13.7 & 232.6 \\
\hline 4. Roosevelt County & 11.2 & 190.1 \\
\hline 5. Union County & 8.4 & 143.4 \\
\hline \multicolumn{1}{|r|}{$|r| r \mid$} \\
\hline State total & \multicolumn{1}{|}{} \\
\hline
\end{tabular}

Most Americans once worked in agriculture: now agriculture, mining and forestry employ only $4 \%$ of all New Mexicans. ${ }^{10}$ The contribution to the state's gross state domestic product is correspondingly small. Organic agriculture constitutes about $3.7 \%$ of the state's agricultural sales.

The pattern of allocation of water resources in New Mexico is a familiar one throughout the West, but the presence of Native American tribes and pueblos raises unique questions. Tribes and pueblos have water rights under federal law. ${ }^{11}$ These rights have been determined for the Jicarilla-Apache and the Mescalero tribes. Settlements of water rights are pending for several pueblos and for a portion of the Navajo Nation's claims.

\footnotetext{
${ }^{8} \mathrm{Id}$.

${ }^{9}$ Id.

${ }^{10} \mathrm{http}$ //factfinder.census.gov/servlet/QTTable?_bm=n\&_lang=en\&qr_name=DEC_2000_SF3_U_DP3\&ds _name=DEC_2000_SF3_U\&geo_id=04000US35

${ }^{\overline{11}}$ Winters v. United States, 207 U.S. 564 (1908).
} 
Litigation and possible settlements are underway for certain other pueblos. The tribal right to control water quality was recognized by the federal Clean Water Act and several entities have received "tribes as states" status, meaning that they can establish water standards for bodies of water that flow on their lands.

Growing population

The Bureau of Business and Economic Research at the University of New Mexico projects a doubling of New Mexico's population from 2005 to 2060 . $^{12}$ The report notes that the population growth will be centered in the Rio Grande corridor cities of Albuquerque, Santa Fe and Las Cruces, mirroring the western trend towards concentration in urban archipelagos. Population growth does not cause a linear increase in water consumption, but without a change in water allocation there will be an increase in overall consumption. For example a subdivision may be built on lands that were agricultural, so that some percentage of the water consumed in agriculture would be consumed by new residents. On the other hand, new residents may use unregulated domestic wells, in which case there will be an increase in water use.

\section{ECOLOGICAL CONDITIONS OF THE STATE'S WATERS}

Ecological conditions in the state's rivers are much harder to characterize. The inattention given to rivers as living organisms is directly reflected in this absence of research: there is no federal law, nor state program, that requires the collection of these data. We do know that $55 \%$ of the state's native fish species are threatened, endangered or already extinct. ${ }^{13}$ We also know the location of threatened and endangered species. There are studies of conditions on specific rivers for specific fishes. ${ }^{14}$ The state has a long standing water quality program, which has classified $31 \%$ of the state's rivers as having water quality impairments. Most importantly, no agency has performed a comprehensive instream flows study for all of the state's waters.

\section{THE POLITICAL AND SOCIAL SETTING}

New Mexicans are concerned about water: it appears on polls, candidate's platforms, and is a constant topic in newspapers. The state commits $10 \%$ of its severance tax funding to water projects administered by the Water Trust Board and substantially more funding is

\footnotetext{
12 The BBER 2008 report does not reflect the current economic downturn.

${ }^{13}$ New Mexico Department of Game and Fish, Threatened and Endangered Species of New Mexico 2008

Biennial Review and Recommendations, available at http://www.wildlife.state.nm.us/conservation/threatened_endangered_species/documents/2008BiennialRevi ew.pdf.

${ }^{14}$ New Mexico Ecological Services Field Office, Threatened and Endangered Species, available at http://www.fws.gov/southwest/es/newmexico/ES_home.cfm
} 
directed to a variety of water projects through other funding mechanisms. (These include federal funding, local bonding, state infrastructure funding sources, etc.)

Several activities associated with rivers have high economic benefits, including fishing, waterfowl hunting, birdwatching, and boating. A very high value has been attributed to fishing and hunting in New Mexico (8,000 jobs, \$456 million in spending, \$49 million in state and local taxes, and $\$ 701$ million in ripple effects). ${ }^{15}$

Wildlife watching also has been assigned a high economic value. ${ }^{16}$

New Mexico: Wildlife-Watching Expenditures and Economic Impacts 2006

New Mexico: Wildlife-Watching Expenditures and Economic Impacts 2006

\begin{tabular}{|c|c|c|c|c|c|}
\hline Retail Sales & $\begin{array}{c}\text { Total Multiplier } \\
\text { Effect }\end{array}$ & $\begin{array}{c}\text { Salaries, } \\
\text { Wages, and } \\
\text { Business } \\
\text { Owner's } \\
\text { Income }\end{array}$ & Jobs & $\begin{array}{c}\text { State and } \\
\text { Local Tax } \\
\text { Revenue }\end{array}$ & Federal Tax Revenue \\
\hline$\$ 297,174,000$ & $\$ 517,789,189$ & $\$ 175,613,450$ & 6926 & $\$ 45,582,882$ & $\$ 34,331,148$ \\
\hline
\end{tabular}

No environmental topic concerning New Mexico can be discussed without acknowledging its poverty. It remains in the bottom five states in per capita income. ${ }^{17}$ The traditional view, especially as often expressed in the New Mexico legislature, is that environmental protection is a costly luxury compared with the benefits of the real economy. As the recession's effects hit New Mexico, the attention of policymakers is focused on job creation and economic recovery.

National advocates have argued that watershed restoration offers one way of putting people to work, as the CCC did in an earlier time. Water efficiency projects also provide ongoing benefits in conserved water and energy. ${ }^{18}$

\footnotetext{
${ }^{15}$ U.S. Department of the Interior, Fish and Wildlife Service and U.S. Department of Commerce, Bureau of the Census. 2006 National Survey of Fishing, Hunting, and Wildlife-Associated Recreation. Washington DC: U.S. Government Printing Office, October 2007.U.S. Department of Commerce, Bureau of the Census. 1997 Economic Census. Washington DC: U.S. Government Printing Office, April 2000.

${ }^{16}$ U.S. Department of the Interior, Fish and Wildlife Service. Wildlife Watching in the U.S.: The Economic Impacts on National and State Economies in 2006; Addendum to the 2006 National Survey of Fishing, Hunting, and Wildlife-Associated Recreation, Report 2006-1 Washington DC: U.S. Government Printing Office, July 2008.

${ }^{17}$ Bureau of Business \& Economic Research-UNM, Per Capita Personal Income by State, 1990 to 2008, available at http://bber.unm.edu/econ/us-pci.htm

${ }^{18} \mathrm{http}$ ://www.allianceforwaterefficiency.org/uploadedFiles/News/NewsArticles/NewsArticleResources/Wat er\%20Efficiency\%20as\%20Stimulus\%20and\%20Long\%20Term\%20Investment\%20REVISED\%20FINAL \%202008-12-18.pdf
} 
The social dimension of water in the state is ever evolving. In northern New Mexicans the acequias are a potent political force; their concerns about protecting culture and water are compatible with river restoration, although this isn't always successfully negotiated. The Middle Rio Grande Conservancy District and the irrigation districts are modifying their relationship to adjoining urban centers and environmentalists, but opposition to the Endangered Species Act, legal recognition of instream flows, and similar hot button causes remains an ingredient of the western culture.

NGOs have played a role in mobilizing support for rivers. WWF has a collaborative program in which it is helping to integrate river management for water deliveries, flood control and habitat protection. National Wildlife Federation and other outdoor recreation groups are building support for the importance of rivers as recreational assets for the state. Hands on projects connect people to rivers: some examples are tree plantings by WildEarth Guardians, Gila river trips by Rio Grande Restoration for the Gila Conservation Coalition, otter restoration by Amigos Bravos, etc.

Finally, there is a string of efforts around the state to restore watersheds, with an emphasis on riparian conditions. These efforts are funded by the US EPA, with pass through funding to the NM Environment Department, under a section of the federal Clean Water Act (section 319) that addresses nonpoint source pollution. The focus of these efforts is riparian management, rather than hydrologic. In addition, the state has provided funding to the NM Environment Department's budget for river restoration. ${ }^{19}$ The NM Environment Department River Ecosystem Restoration Initiative has solicited applications for projects that directly affect the physical condition of rivers, including environmental flows.

\section{A STRATEGY FOR MOVING FORWARD}

It is an opportune time to take action to protect and restore New Mexico's waters. Water remains high on the priorities of the public and elected officials. A new Congressional delegation contains members with deep commitment to the state's environment. The relevant federal agencies are considerably more inclined to environmental protection than in the past. Despite the lukewarm interest of many water managers within the state and a lack of experience in the legislature, indicators of change are widespread.

The agenda sketched out below is focused on the steps that are necessary to protect and restore the state's rivers. The emphasis is on how to modify the institutional framework for restoration to improve the physical conditions of the state's waters.

\section{A. New Water Projects}

Background: New Mexico continues to pour hundreds of millions of dollars into the construction of new water projects, with virtually no environmental scrutiny nor challenges. The size of these projects ranges from very small (perhaps $\$ 100,000$ -

\footnotetext{
${ }^{19}$ New Mexico Environment Department, The River Ecosystem Restoration Initiative (RERI), available at http://www.nmenv.state.nm.us/swqb/reri/
} 
$\$ 500,000$ for removal of riparian vegetation, to projects in the hundreds of millions of dollars. There is no environmental group that regularly scrutinizes these projects. On occasion, as with the Gila River, a group opposes federal appropriations and state development efforts. The authorization for the San Juan-Chama diversion occurred before environmental advocacy took hold in the state, but aspects of its implementation have been challenged in both Albuquerque and Santa Fe.

The National Environmental Policy Act (NEPA) provides for review of federally funded projects. However, the proponent agency reviews its own proposals and does so long after the project has been endorsed by the myriad of agencies involved in actions. An active citizens group can use NEPA to change this dynamic, but thus far there is no group in New Mexico with the funding to systematically review proposals. In general, projects are proposed by the state to the federal government for funding, so that federal review comes long after a state commitment has been made. ${ }^{20}$ Thus, NEPA, which potentially could be a tool in requiring more examination of water projects, does not provide a level playing field for the review of projects and is unlikely to provide the means of reversing a commitment, absent extraordinary citizen involvement.

Tribal water settlements are one of the strongest illustrations of this. The Navajo settlement ${ }^{21}$ which contains funding for developing water from the San Juan River and building a pipeline to Gallup, was negotiated by a group of water users, without environmental participation. There is some vocal opposition to the project by Navajo activists, but no opposition on environmental grounds was voiced in Congress.

The state does not provide its own NEPA-type review. New Mexico had a state NEPA for one year, ${ }^{22}$ but it was repealed at the instigation of the powerful state engineer, Steve Reynolds.

\section{Recommendations}

The state should adopt a least cost approach to water projects, which would provide a basis to scrutinize financial and environmental costs. The state should switch from the current emphasis on water supply to addressing water demand through efficiency. Not only is efficiency less expensive, it also reduces the enormous energy demand associated with water projects.

\footnotetext{
${ }^{20}$ Two massive water projects in which Santa Fe and Albuquerque divert water from the Rio Grande (actually, Colorado River water) are examples of this. Long before environmental impact statements were prepared, the cities and the state had invested in project design and committed funds to the projects, and had procured federal support for the water contracts. It is difficult to imagine that any NEPA review could have resulted in a different approach, coming that late in the political processes.

${ }^{21}$ Federal funding is provided by the Navajo-Gallup Water Supply Project, Pub.L.No. 111-11, SS 10601609, 123 Stat.1379-96.

${ }^{22}$ Comment, The Rise and Demise of the New Mexico Environmental Quality Act, "Little NEPA", 14 NAT. RES. J. 401 (1974).
} 
Even if the federal government bears much of the burden, the state will still have to contribute a share. The Gila River diversion proposal, in which the federal government will contribute up to $\$ 160$ million for a river diversion project, is an illustration of this. ${ }^{23}$ While the state views this money as "free," in fact it already has spent millions of dollars of state money on project planning, staff time and lawyers; likely will spend millions more to construct a project; and will be responsible for the sizable operations and maintenance costs of the projects. State legislators and the executive branch need policy analysis to bring about a better understanding of the costs of these projects. There is a surprising lack of scrutiny by the Congress of water projects, which encourages states to seek funding for projects that would not fare well in competition for state funding. ${ }^{24}$

Citizens, of course, end up paying for these projects through tax dollars or through lost opportunity costs as spending is diverted from other needs. Unfortunately the availability of mechanisms such as severance tax bonds obfuscates these costs and leads to a liberality that is not seen in local elections to raise taxes.

\section{B. WE NEED TO PURSUE REGULATORY AND STATUTORY REFORMS}

This section proposes a series of actions to improve the quality of the state's rivers. The strategy underlying each of them recognizes that protection of rivers needs to become part of the ethos of the state, so that both citizens and government recognize that the destruction of rivers is unacceptable. The nonprofit sector can be an inspiration and a goad to public action, but ultimately river health should be part of our government's mission, incorporated into agencies' mandates, just as other social movements have been incorporated over time.

\section{A mandate for restoration}

The greatest obstacle to protection of the state's rivers is conceptual; there is no expression in state law of the value of rivers in themselves. In other words, there is no organic act expressing a state mandate that waters should be protected for attributes related to their own functions. Rather, rivers are put within a reductionist framework in which they are valued for the water they contain or for their function to convey water to downstream entities. The result is that natural functions of rivers are ignored in water resource decision making.

In contrast, when society values something in nature, its boundaries are established and direction is given for the values for which it is to be managed in the future. Examples of these places include Yellowstone and Yosemite National Parks, the Everglades, but also

\footnotetext{
${ }^{23}$ Arizona Water Rights Settlement Act, P.L. 108-451, 118 Stat. 3478 (2004)

${ }^{24}$ See, Denise D. Fort, "Keep Your Money: Let the West Pay for its Own Water Projects," 27 Public Lands Law Review 15 (2006).
} 
the estuaries of the United States ${ }^{25}$ and the Columbia River. ${ }^{26}$ States also have protected rivers from federally licensed diversions using the Clean Water Act, ${ }^{27}$ protected riparian areas, ${ }^{28}$ and provided legal protections for instream flows. ${ }^{29}$ An organic act for rivers need not mean an end to their use, but rather that the value of the river itself is considered in decision making about its use.

A state law should be crafted that requires that river health be considered in decision making over water and other activities that affect waters, that agencies evaluate state actions that may affect rivers, and that requires state agencies to pursue restoration through federal and state appropriations.

\section{Federal support}

Federal agencies direct hundreds of millions of dollars to restoration projects across the United States, but almost nothing to New Mexico (The restoration efforts on the middle Rio Grande are the major exception). Examples include the familiar ones of the Columbia River Basin, the California Bay Delta, the Platte River, the Everglades, and an entire program for Estuary Restoration, of which the Chesapeake Bay has been a leading recipient. These funds may be directed through the Bureau of Reclamation, through the Water Resources Development Act (the Corps of Engineers), the U.S. International Boundary and Water Commission or through stand alone legislation directed at particular rivers. Rather than pursuing restoration funds, the state, through the Office of the State Engineer and the Interstate Stream Commission, seeks billions for conventional water projects, in which water is pumped, piped, and distributed in new locations.

If New Mexico is to seek federal support for restoration, the state will need to prepare proposals for funding. This will require that it catalogue what rivers or stretches of rivers can be restored, and work with federal agencies and the Congressional delegation in preparing proposals for funding. Affected communities should be brought into the process of developing proposals for restoration.

3. Protection of all waters and of the riparian environment from pollution and alteration.

In the Rapanos case, the U.S. Supreme Court significantly narrowed the reach of the Clean Water Act. ${ }^{30}$ The case concerned the meaning of "navigable waters," an

\footnotetext{
2533 U.S.C. $\$ 1330$ (West 2009)

${ }^{26}$ Pacific Northwest Electric Power Planning and Conservation Act, Pub. L. No. 96-501, 94 Stat. 2697 (1980) (codified as amended at 16 U.S.C. $\S \S 839$-839h (2006)).

${ }^{27}$ PUD No. 1 of Jefferson County v. Washington Dept. of Ecology, 1994.

${ }^{28}$ ARIZ. CONST. ART. 17, §1 (West 2009); ARIZ. REV. STAT. ANN. §§37-1101, 45-101 (West 2009).

${ }^{29}$ OR. REV. STAT. ANN. $\$ \S 537.332$ to .360 (West 2009); IDAHO CODE ANN. \$42-1501 (2009); WASH. REV. CODE ANN. §90-22-010 (West 2009); MONT. CODE ANN. §85-2-316 (2009); ALASKA STAT. \$46.15.145 (2009); CAL. WATER CODE §1707 (West 2009); COLO. REV. STAT. ANN. §37-92102 (West 2009); WYO. STAT. ANN. §§41-3-1001 to -1014 (2009); KAN. STAT. ANN. §§82a-703a to 703c (2009); NEV. REV. STAT. ANN. §533.030 (West 2009); ARIZ. REV. STAT. ANN. §45-101 (West 2009); UTAH CODE ANN. §73-3-30 (West 2009); NEB. REV. STAT. §§46-2,107 to ,119 (2009).

${ }^{30}$ Rapanos v. United States, 547 U.S. 715 (2006).
} 
unfortunate choice of words by the authors of the 1972 Clean Water Act. The Court refused to support an expansive reading of the phrase, rather interpreting it narrowly to refer to perennial waters and directly connected wetlands. This decision has enormous consequences for protection of New Mexico's waters, both in terms of water quality, but also in terms of preventing destruction of wetlands and features such as prairie potholes. ${ }^{31}$ Legislation has been introduced in the Congress that would clarify the intent of the Congress with respect to protected waters and wetlands. ${ }^{32}$ Further, there is a lurking Constitutional issue about the ability of the Congress to regulate nontraditional water bodies, such as isolated wetlands. (In summary, some Justices believe that the Commerce Clause is not sufficient to support federal regulation without a showing of a link between the regulated activity and interstate commerce. This showing would be difficult to make in particular cases.) In New Mexico, playa lakes are examples of waters that would be difficult to protect under some constitutional interpretations.

For these reasons, New Mexico must exercise its unquestioned authority over each of these types of water features. The problem is not that New Mexico cannot regulate these bodies, but that is has yet to do so. There are several types of regulation that are needed and the discussion necessarily is complicated. First, New Mexico does not administer the federal Clean Water Act point source pollution program, the NPDES program (National Pollutant Discharge and Elimination System). While some state officials would like to do so, the likely political trade off is that the state must disclaim any greater authority than the federal government has. There would seem to be no benefits for the environment for the state to assume the program under those conditions. Administration by the remote EPA has both costs and benefits for the environment: the enforcement presence has been pallid from the Dallas regional office, but any environmental program in New Mexico is subject to the political influence of the Governor in command. Second, the greatest environmental loss from the Supreme Court decision is in the protection of wetlands. (Section 404 of the Clean Water Act protects wetlands from "dredging and filling" without a permit.) There are numerous exceptions, poor administration, and similar deficits, but the program has required developers and others to pass through a review, often to acquire off-sets, and occasionally led to the EPA veto of a project. EPA just vetoed a large Corps of Engineer's project in Mississippi under this section. New Mexico does not have a comparable statutory provision. Finally, the state should protect its riparian areas, not just their water quality and associated wetlands. (Needless to say, a wetland in New Mexico doesn't look much like one in Maryland. The scientific definition of a "wetland" has been hotly contested, but it is not likely to encompass more than a very thin ribbon of vegetation along a river or creek.). Many western states or substate units have statutes providing protection for riparian corridors, which may protect water quality, aesthetics, habitat, and the public treasury from paying for flooding emergencies. Of course, the carrots of conservation easement programs also can be used. (The federal government's programs under the Farm Bill, administered by the Natural Resources Conservation Services, are relevant, but have proven to be disturbingly fickle.)

\footnotetext{
${ }^{31}$ J. Brian Smith, Western Wetlands: The Backwater of Wetlands Regulation, 39 NAT. RES. J. 357 (1999).

${ }^{32}$ Clean Water Restoration Act of 2009, S. 787, $111^{\text {th }}$ Cong. (2009).
} 
Strengthen the Strategic River Reserve

The state has a designated fund for purchasing waters for compact deliveries and to meet the needs of endangered species, called the Strategic River Reserve. ${ }^{33}$ Thus far, the state's implementation of the law has been weak, especially with respect to purchasing water for endangered species. Nonetheless, the fact that water can be dedicated to instream flows represents a sea change in the state's position on beneficial uses of water. The fund does not have a dedicated source of revenues. Further, the legislation establishing it restricted purchases of water to situations where the ESA has been invoked or for purposes of compact deliveries. This is unnecessarily restrictive, in that it limits the purchase of water to endangered species, rather than the broader ecological purposes that are needed for river protection. The language should be amended to remove the restriction on the purposes for which water can be put into the Reserve.

The state needs to assess its rivers so that it can pursue restoration of flows under established criteria. A minute fraction of the state's current water development budget goes to the Reserve and a minute fraction of the state's rivers are protected. ${ }^{34}$ The public would support more balance between exploitation and protection of the state's rivers.

Establish private instream flow rights

New Mexico is at the bottom of a common measure of a state's river protection: it is often cited as the only state that does not have a statute to protect instream flows. As discussed above, the state has recognized instream rights under the state Strategic River Reserve and, as a practical matter, has cooperated in providing de facto protections for instream flows on the Rio Grande and the Pecos Rivers. Further, an opinion by then Attorney General Udall, which was approved by then Engineer Eluid Martinez, delineated conditions under which an instream flow right could be established by a private applicant. (See, Fort, "Instream Flows in New Mexico," 7 Rivers 155 (2000))

The ability of a private applicant to create and hold an instream flow right remains unclear because the popular perception is that there is no such ability and it appears that such a private right has yet to be granted. ${ }^{35}$ The OSE/ISC initiated a regulatory development process that would have delineated conditions under which such a right could be established; it was abruptly cancelled in May of 2008. The legal opinion of the Attorney General provided a compelling analysis that New Mexico's law and constitution permitted instream flows as a beneficial use and that no statutory change is necessary to accomplish this change. Why, then, has so little happened at the OSE/ISC to bring New Mexico into step with other western states?

33 N.M. STAT. ANN. §72-14-3.3(B)(2) (West 2009). “(B)Water and water rights in the strategic water reserve shall be used to ... (2) assist the state and water users in water management efforts for the benefit of threatened or endangered species or in a program intended to avoid additional listings of species."

${ }^{34}$ Professor Larry MacDonnell discusses the potential for the use of the act in Environmental Flows in the Rocky Mountain West: A Progress Report, 9 Wyoming Law Review 335 (2009).

${ }^{35}$ Our research does not indicate that any application for a private right have been denied, however. 
Clearly state agency personnel are part of a culture in which instream flows are considered risky and illegitimate. Steve Reynolds, who held the Engineer post during the terms of many different governors, is the intellectual father of today's water agencies and was an adamant opponent of instream flows. For many years, organized agricultural interests, which were and are a powerful interest group in New Mexico's state legislature, resolutely opposed instream flows. There are cracks in this opposition as the benefits of the Strategic River Reserve become apparent. ${ }^{36}$ The acequia community was a harsh opponent of instream flows, but better working relationships between these communities and environmental organizations, and protection secured by acequias for protecting water rights against transfers may indicate that legislation could be acceptable to them. Indeed, insofar as water is no longer being used in agriculture, short term leases of water for instream flows might help against abandonment actions. ${ }^{37}$

If a private water rights owner desires to dedicate flows to instream uses, or to transfer a right to an entity that wishes to do so, the matter would be ripe for decision by the State Engineer. In any water transfer (whether of ownership or point of diversion), the facts would be critical to the Engineer's decision making. The abstract concept of instream flows would be evaluated in a specific context. One can imagine factors that could bear in favor of granting an instream flow, such as the support of a downstream water user, or a benefit for the state's compact obligations. One can also imagine factors that would make it more difficult to get the Engineer's approval, such as a dispute over whether rights had been abandoned, or if there were opposition from an acequia. It seems unlikely that a decision would be based on a pure legal ground that instream flows cannot be granted in New Mexico. If the decision were framed as a policy matter, it would be appropriate to seek the direction of the Governor.

Depending, therefore, on the merits of the decision, an aggrieved landowner could pursue an appeal. The environmental community also could seek legislative support for a rule supporting instream flows and removing administrative hurdles.

Establish a trust to hold instream flow rights

The land conservation movement has demonstrated that many citizens want to see their land protected into the future from development. The mechanism is straightforward: to simplify, donations of land in fee, or of development rights in land, are made to a nonprofit. The nonprofit protects the interests into the future. ${ }^{38}$ In exchange for the

\footnotetext{
${ }^{36}$ The state's attempts to meet its compact obligations on the Pecos River predated the Strategic River Reserve and constituted an instream flows program, albeit for compact compliance rather than ecological purposes. In it the state spent millions of dollars to buy water to put into the Pecos for these purposes.

${ }^{37}$ Under New Mexico law, a water rights holder who fails to put water to beneficial use may run the risk of losing water, either in an adjudication or should the holder attempt to sell the right to another. cites

${ }^{38} 26$ U.S.C. s.170; See, Elizabeth Byers, The Conservation Easement Handbook (2 ed., rev. 2005); The Land Trust Standards and Practices Guidebook: An Operating Manual for Land Trusts (Sylvia K. Bates \& Tammara Van Ryn, eds., 3 ed., 2006).
} 
donation, the donor may receive a federal tax benefit. In New Mexico, a state tax credit is available for donations of land and water. ${ }^{39}$

There are a number of land owners in the state who may have water rights to donate or sell a trust, usually in conjunction with a donation of land. One unresolved question is whether they could receive a federal tax benefit from doing so. The state law is clear that a tax credit is available.

It may be most desirable for a trust to be able to hold both land and water, because a donor may well have both interests. It is certainly desirable to ascertain if any of the state's existing land trusts would be interested in holding instream flow rights.

\section{Legislation to protect Natural Resources}

New Mexico has lands of high recreational, environmental, and aesthetic value that are privately owned and subject to development in the future. The state's conservation organizations have tried to establish a program for purchase of these lands. These proposals have included money for purchase of water associated with them, since water is such a critical part of the landscape. In some instances, the water would be dedicated to a river, rather than used upon the land, and thus instream flow protection would be necessary.

\section{The Public Trust Doctrine}

The concept that the public has a role in the protection of certain natural resources has a long lineage in the common law. A landmark case in California applied the doctrine and held that water allocation policies that failed to protect environmental values in Mono Lake violated the public interest. ${ }^{40}$ That case may have marked the high water point of the doctrine, but it remains a valid template for balancing the management of natural resources. Certainly the complete dewatering of a river, as we have experienced in New Mexico, could be a basis upon which a court would require that attention be given to public interests in a river. The doctrine is a common law, not a statutory right and it is vindicated in state courts. New Mexico has a paucity of environmental cases, so it is difficult to forecast how an appellate court would respond to such a case. ${ }^{41}$

The concept that water should not be privatized has been a rallying cry for over a decade. Ironically, in New Mexico water rights have been privatized for many decades and the relevant question is how we can recreate a public interest in our rivers, springs, and lakes.

\footnotetext{
${ }^{39}$ N.M. STAT. ANN. §75-9-5 (West 2009).

${ }^{40}$ National Audubon Society v. Superior Court, 658 P.2d 709 (Cal., 1983).

${ }^{41}$ See discussions in Lisa D. Brown, The Middle Rio Grande Conservancy District's Protected Water Rights: Legal, Beneficial, or Against the Public Interest in New Mexico?, 40 Nat. Resources J. 1, 3 (2000); Consuelo Bokum, Implementing the Public Welfare Requirement in New Mexico's Water Code, 36 Nat. Resources J. 681, 690 (1996).
} 
The public trust is related to the argument that water should not be commodified. ${ }^{42}$ The opponents of private ownership of water often refer to the context in which a municipal water supply is purchased by a corporation. In the American West, most aspects of water ownership do reside in private hands. The salient question is how to protect what should be publicly protected, such as the environmental and aesthetic value of a river.

Water Management in New Mexico and the Organization of New Mexico's water related agencies and personnel decisions

It is hard to overstate the challenges in water management that New Mexico faces and how difficult it will be to meet these challenges. In addition to the environmental failures that are the subject of this report, the immediate problems include: unadjudicated water basins, the lack of agreements concerning water development on pueblo lands, water transfers that do not reduce water use on the originating land, municipal growth decisions that are made in advance of identification of legitimate water supplies, groundwater mining that results in the urgent need for new water supplies, subsidence, water speculation, expensive commitments to unreliable water supplies, the failure to control widespread use of domestic wells, and the wasteful use of water because of its low or nonexistent cost to users. The institutional failures that have given rise to this mess are many, but perhaps the primary one is that the prior appropriation law was not designed to "manage" water, but rather to create private rights, and the state agencies' authorities spring from a limited role in administration of water rights.

The institutional structure of the state's water management agencies also seems designed to promote poor management of water. New Mexico's water allocation agency came into existence at the turn of the last century to administer water rights that already were the source of dispute and contention. Water quality is administered by another agency (the Water Quality Control Commission of the New Mexico Environment Department). Further, water quality regulation is split among agencies, with mining, oil and gas pollution partially handled by the Energy, Minerals, and Natural Resources Department and agriculture by the New Mexico Department of Agriculture. There is a minimal link between water quality decisions and water quantity decisions from the presence of the State Engineer on the Water Quality Control Commission, but there is no comparable environmental presence in the decision making by the State Engineer. It takes no great insight to see the merits of integrated water management, in which quality, ecology, and water rights are managed for common ends. Other states have moved in this direction. ${ }^{43}$

An anachronistic feature of New Mexico water law is the requirement that the state employ a Professional Engineer as the head of the Office of the State Engineer. ${ }^{44}$ Even if more widespread reform were too difficult to achieve, it would be useful to rename the Office of the State Engineer, "the Water Resources Office," and to be able to choose

\footnotetext{
${ }^{42}$ Maude Barlow, Blue Covenant: The Global Water Crisis and the Coming Battle for the Right to Water (2008).

${ }^{43}$ David H. Getches, Lawrence J. MacDonnell \& Teresa A. Rice, Controlling Water Use: the Unfinished Business of Water Quality Protection (1991).

${ }^{44}$ N.M. STAT. ANN. §72-2-1 (WEST 2009).
} 
among skilled professionals in water management from any appropriate field, such as hydrology, law, economics, and related disciplines. ${ }^{45}$

Reforming bureaucracies can be done, typically by a Governor at the beginning of a term when agency heads are less likely to fight for the status quo and when the legislature extends some consideration to a Governor's desire to manage as she sees best. On the other hand, restructuring of agencies takes political capital that a Governor may prefer to save for better understood measures.

Because of water's importance, there are many with interests in how water is managed in the state who have opinions about how the state's administrative structure and functioning could be improved. Prior to introduction in the legislature, proposals could be brought to these parties. Unfortunately, there is no single forum that is representative of all of the state's water interests, but it is possible to reach many citizens through citizen initiatives such as the Water Dialogue. ${ }^{46}$

\section{Conclusion}

We live in an arid state, with climate change bearing down on us, and with a limited time to protect the natural systems of which we are a part. Extinction of species is the most extreme manifestation of the threat, but the massive spending on water projects indicates how capable humans are of utilizing natural wealth. Without balance, the rush to acquire "new" water quickly will foreclose our ability to restore functioning in these systems. The institutional reforms discussed above are well within our collective abilities to demonstrate our stewardship of the state.

\footnotetext{
${ }^{45}$ Rep Brian Egolf attempted to broaden those who could hold the position in the 2009 legislative session, but the bill was vehemently opposed by the State Engineer and died in committee. H.B. 473, 49 Leg.

Sess.,1st Reg. Sess. (N.M. 2009).

${ }^{46} \mathrm{http}: / /$ www.nmwaterdialogue.org/
} 